\title{
The NGO Community in China
}

Expanding Linkages With Transnational Civil Society and Their Democratic Implications

\section{Chen Jie}

\section{(2) OpenEdition}

12 Journals

Electronic version

URL: http://journals.openedition.org/chinaperspectives/3083

DOI: $10.4000 /$ chinaperspectives.3083

ISSN: 1996-4617

\section{Publisher}

Centre d'étude français sur la Chine contemporaine

\section{Printed version}

Date of publication: 1 November 2006

Number of pages: $29-40$

ISSN: 2070-3449

\section{Electronic reference}

Chen Jie, «The NGO Community in China », China Perspectives [Online], 68 | november- december 2006, Online since 01 December 2009, connection on 28 October 2019. URL : http://

journals.openedition.org/chinaperspectives/3083 ; DOI : 10.4000/chinaperspectives.3083

This text was automatically generated on 28 October 2019

(c) All rights reserved 


\title{
The NGO Community in China
}

\author{
Expanding Linkages With Transnational Civil Society and Their \\ Democratic Implications
}

\section{Chen Jie}

1 This article looks at the growing democratic implications of the expanding relations between the community of non-governmental organisations (NGOs, or 民间组织 minjian zuzhi) in China and transnational civil society (TCS). It starts by explaining TCS and global governance, providing a framework for the analysis it offers. The second section presents a brief profile of Chinese civil society. The following two sections explore the increasing transnationalisation of China's NGOs and its subtle democratising impact. Due to the complexity of the emerging phenomenon of the transnationalisation of Chinese NGOs, some of the main arguments in this article are only tentative. Further statistical and empirical research is needed.

2 Besides mainly contributing to the discussion of China's socio-political pluralisation and democratisation from a meaningful new perspective, this article also fills a major lacuna in both China and TCS research. Transnational dimensions of civil society have been neglected by mainstream China scholars studying the country's politics and society. Studies of China's international relations are predominantly state-centric or business-centric, placing little attention on civil society's solidarity with the transnational NGO milieu. Meanwhile, China has long been ignored by the published literature on TCS, unlike some South American countries and India, from where the grassroots social and environmental campaigns are often used as case studies in discussing TCS.

TCS and global governance

3 China faces a world that is witnessing a growing interconnectedness of TSC, multinational business, states and inter-governmental organisations (IGOs), in an emerging and loosely structured framework of global governance. The post-Cold War world has seen a massive proliferation of NGOs across the world, and a "global associational revolution"-an upsurge around the world of organised voluntary activity and the creation of private, not-for-profit or non-governmental organisations. Associations, foundations and similar institutions were formed in numerous countries 
to deliver human services, promote grass-roots economic development, prevent environmental degradation, protect civil rights, and champion gender equality ${ }^{1}$.

Reflecting a major phenomenon in the post-Cold War world politics, transnational civil society refers to the rapidly expanding cross-border co-operation and networking by NGOs, private foundations and activist research centres from various countries. Such transnational collaboration in shared ideas, funding, advocacy and campaigning seeks to challenge the status quo or provide services in the areas of human rights, labour, women, environment, indigenous affairs, humanitarian relief, poverty alleviation, corporate globalisation, peace and security, and health epidemics. The most important single actors in this cause-oriented movement of "globalisation from below" are the sort of NGOs which are by definition transnational, namely those NGOs that maintain their own branches in many countries. These so-called INGOs (International NGOs) include Oxfam, Save the Children International, World Vision, Amnesty International, Transparency International, Greenpeace International, and World Wide Fund for Nature, etc. It is estimated that today there are 12,260 INGOs and 5,807 internationally oriented national NGOs ${ }^{2}$. The growing number of transnational networks and collaborative arrangements among non-profit and non-governmental organisations across the world can be attributed to their common economic, social, cultural, environmental, political and security concerns. Under the pressures of globalisation in a variety of issue areas, many similar challenges face human society, requiring transnational responses. Yet governments are increasingly limited in their ability to deal with those problems. Meanwhile, developments such as the dismantling of the cold War ideological barrier and technological advances in communication and transportation have improved the conditions that make transnational actions possible.

NGO networks and their key members are playing an increasingly prominent role in world politics. Global governance refers to collective efforts by states, IGOs and nonstate actors at a global level to tackle issues and challenges of common concern to the international community. Despite their fragmentary and fluid nature, such collective efforts have become more institutionalised and operate with increasing use of international law, though their cohesiveness varies in different issue areas. Both formally and informally civil society activists take an active part in a host of key IGOs, particularly the UN and its specialised agencies, and many international treaty bodies focused on more specific issues. It has become a norm that the major international conferences organised by IGOs or state treaty bodies also hold parallel NGO forums, in order for non-state actors to take part in international policy discussions. Through such participation in policy debate, standards-setting and norm-making, non-state actors help reform policies of states and IGOs. Those arrangements, materialising partly under the pressure of transnational actors themselves, have provided a catalyst for the formation of many INGOs. A special institutionalised mechanism within the UN is the so-called "consultative status", designed to give citizen groups access to influencing policy-making at the global level. The UN Charter specifically says that the Economic and Social Council (ECOSOC) should take measures to consult non-state actors regarding affairs in its field. By 1992 more than seven hundred INGOs and internationally oriented NGOs had attained consultative status and the number has steadily increased ever since to more than 2,300 today ${ }^{3}$. In summary, Ghils maintains that INGOs exert influence in world politics in three ways: as shapers of opinion, as autonomous actors, and as competitors with states ${ }^{4}$. 
A brief profile of China's NGO community

Since the 1980s, there have been mounting issues and challenges calling for citizens in China to organise in order to articulate and pursue shared interests. Competing interests and constituencies within Chinese society have emerged as a result of economic reform and the modernisation drive. Growing numbers of activists have thus established organisations, networking and expanding. However, although generally there is more space for an autonomous NGO sector to develop, the government harbours anxieties about social "instability", imposes severe restrictions on NGOs' activities and bans the formation of any autonomous organisation in politically sensitive issue areas such as human rights and the free movement of labour. Thus autonomous citizen groups are predominantly concentrated in what the authorities deem as less threatening areas of social service provision, economic development, gender equality and domestic violence, environment, migrant workers, children, the disabled, and animal protection. Beijing knows that administrative structures alone are unable to manage all those issues, particularly considering its acute budgetary pressures and its desire to streamline administration ${ }^{5}$. Some international events, such as the US bombing of Chinese embassy in Belgrade (1999), the invasion of Iraq, and, in particular, the Japanese government's provocative acts signifying a lack of remorse over Tokyo's wartime atrocities, also led to the networking and organising of agitated Chinese citizens. However, fearing the scenes of voluntary protests, the authorities suppressed those activities as soon as their politico-diplomatic value was exhausted.

7 The fear of bottom-up social mobilisation as well as practical needs have led the government to create a semi-official NGO sector, a policy practiced with increasing enthusiasm from the 1990s. Government and Communist Party departments at various levels have been setting up foundations and other organisations to advance charitable, research, information and policy objectives. These creatures are commonly called "GONGOs" (Government Organised NGOs). One major category of GONGO is born of traditional Leninist mass organisations (人民团体 renmin tuanti). There are eight of them, including the All China Youth League, All China Women's Federation, and the All China Federation of Trade Unions. The government is trying to gradually restructure the function of these mass organisations away from their original role as Communist Party overseers of particular constituencies, towards one more of service facilitation and provision. As a result, satellite agencies (associations and foundations) have been created. There are two major purposes of the GONGO sector. One is to receive expertise and philanthropic funding that the government itself finds hard to access, particularly from international sources including INGOs. Some government departments establish organisations in their professional field with the apparent purpose of making it possible to conduct exchanges with international organisations and to participate in overseas study tour programmes in an unofficial capacity. Another consideration is that at some distance from mainstream government agencies makes it easier for government-initiated organisations to explore new areas of work, such as providing contraceptive advice for unmarried people, or HIV/AIDS prevention programmes for sex workers and drug addicts ${ }^{6}$. With few exceptions such as the China Society for Human Rights Studies, established to serve the authorities' human rights diplomacy as well as study international standards, GONGOs' areas of interest are similar to those of the more autonomous groups. Both are predominantly concentrated in the areas of social service provision, economic development, women's rights and environmental protection. 
8 Autonomous NGOs and GONGOs together constitute China's NGO community. Statistics from the Ministry of Civil Affairs suggest that today, officially registered NGOs including GONGOs in China numbered 244,000 ${ }^{7}$. The total number of bottom-up and self-governing autonomous NGOs is unknown. But Chan estimates that in 2000, around 26,000 registered social organisations in China could be classified as "NGOs in a Western sense" ${ }^{8}$.

The transnationalisation of China's NGO community

9 TCS connections of Chinese NGOs of both the above categories have expanded dramatically over the past decade, which is a major factor in the recent growth of Chinese civil society and some of its accomplishments. Activities by autonomous groups like Friends of Nature, Global Village of Beijing, Green Earth Volunteers, Maple Women's Counselling Centre, Village Women Know It All, and Aizhi Action have become well known in transnational campaign networks.

Participation on four fronts is essential to NGOs in any country if they are interested in TCS and global governance. First is participating as observers in the forums of the UN, its specialised agencies, and various international treaty bodies, in order to take part in international policy discussions. The most important form of such participation is to enjoy a UN consultative status. The All China Women's Federation, China Society for Human Rights Studies and China Disabled Persons' Federation (the latter two are major GONGOs) enjoy such status. The second front of participation is the NGO forums which are wholly for civil society but nonetheless organised by the UN system. For example, Friends of Nature attended the NGO forum of the World Summit on Sustainable Development (Johannesburg, 2002), and numerous Chinese women groups participated in the NGO forum in parallel to The Fourth World Conference on Women (Beijing, 1995). The third front is membership in major INGOs, and the fourth is the more loosely structured transnational forums which are organised by the different countries' NGOs themselves, with both hosts and participants being exclusively NGOs. For example, Chinese women's NGOs have been participating in the East Asian Women's Forum, a biennial event organised by Asian women NGOs since 1994.

11 The above general model, created from my own research on TCS ${ }^{9}$, is useful for study of Chinese NGO interaction with foreign NGOs, since such interaction occurs on all those four fronts. However, empirical indications are that the most important site of interaction is the home turf of Chinese groups, namely their co-operation with INGOs for projects operated in China itself, while expanding membership in INGOs is also a significant indicator of interaction. Before exploring such interactions, it is helpful to draw a bigger picture of Chinese NGOs' transnational relations by discerning two kinds of relationship-or two parallel relations-between Chinese NGOs and TCS. In the eyes of the authorities, one is illegitimate and the other is legitimate and often encouraged, as explained below.

12 The first kind of relationship is part and parcel of TCS campaigns against the Chinese state on human rights, labour, Tibet and other high political concerns. This usually involves INGOs like Amnesty International, Human Rights Watch, Reporters Without Borders, Pen International, Transnational Radical Party, etc. They rely on key information provided by those banned or underground groups inside China such as The Tiananmen Mothers, formed by parents campaigning to hold the government accountable for their student children missing in the 1989 incident, and Independent Chinese Pen Centre, a forum of dissident writers championing freedom of expression. 
On the other hand, the most active Chinese sections of those co-ordinated transnational campaigns are the Chinese dissident groups in exile, often headquartered in the United States. The principal ones would include Human Rights in China, specialising in research, documentation and lobbying; the Overseas Chinese Democracy Coalition, an umbrella for many hard-core activist groups based in the West; and the various campaign networks fostered by the Falun Gong religious movement, which moved abroad after it was banned in China in 1999. With crucial information provided by domestic groups, those INGOs and particularly the leading dissident groups expose the Chinese government at the annual sessions of the UN Commission on Human Rights in Geneva, try to influence various governments' opinions at such forums, and lobby the United States Administration and Congress. Such advocacy networks do protect some domestic activists by giving them much international limelight, financial and moral support, prizes, and occasionally even helping in the release of jailed activists and writers. On the other hand, the impact that transnational rights campaigns have on China's political development is debatable.

In the above kind of relationship the most important NGO parties (namely INGOs and Chinese groups in exile) must stay out of China while working on China. Yet under the second kind of relationship, which is the focus in this paper, members in China's domestic NGO community co-operate with international groups in permitted ways and issue areas, and even encouraged by the Chinese government. This usually means that the interested INGOs can operate within China if they wish. Conservative estimates suggest that more than 490 INGOs (such as Save the Children, Oxfam, and the Lions) and major international foundations (including Ford Foundation and The Rockefeller Foundation) have set up projects and opened offices in China ${ }^{10}$. It is impossible to calculate the exact number of international groups operating in China because many do not have offices or staff permanently based in China. According to Wang Ming (王名), Director of NGO Research Center, Tsinghua University, there are between 3,000-6,000 foreign NGOs based in China, including about 2,000 foundations, 1,000 implementing groups, 2,500 chambers of commerce, and 1,000 religion-based organisations. He claims that most are not registered, but operate under silent endorsement from the authorities ${ }^{11}$. On another front, according to the Yearbook of International Organisations, China's membership in INGOs increased steadily in the reform era, from 71 INGOs in 1977 , to 484 in 1986, and 2,297 in $2002^{12}$.

As for the percentage of Chinese NGOs that have developed transnational linkages, one can only provide an informed impressionist picture. In a major piece of research conducted recently by the NGO Research Center at Tsinghua University, questionnaires were circulated to 226 people representing 249 NGOs of various types in six provinces/ cities (Yunnan, Shanghai, Beijing, Liaoning, Hunan, Gansu), and $17 \%$ stated that a significant number of Chinese NGOs were joining international networks, and reaping benefits by way of funding, exchange of information and technology, and staff training. Over $40 \%$ thought that few or even none had developed transnational relations. The remaining $40 \%$ did not answer this question ${ }^{13}$. Considering that Chinese civil society itself is still not strongly developed, and transnational NGO linkages were little heard of in China during the 1980s, the above figures should be read positively. The final report by the NGO Research Center points to a rapidly emerging and developing trend by concluding that NGOs in China "are making more and more contact with international organisations" ${ }^{14}$. 
INGOs operating in China appear to mostly base their programmes in poor regions, particularly south-western China such as Yunnan Province, while also maintaining representation in Beijing. A Beijing office helps in connections to the central political system, considering the uncertainties of the existing regulatory framework within which civil society actors operate. Concentration in the poor provinces reflects China's overall restrictive policy towards civil society. Such restrictions on the nature and scope of domestic NGOs naturally translate into the sort of transnational relations between Chinese and international groups. Thus transnational projects of Chinese NGOs cannot occur in any politically sensitive issue area and cannot involve any political or militant INGOs. Under this policy, INGOs that are allowed to work within China are mostly humanitarian, development and environmental groups that usually take less interest in rich provinces and set their sights on the poor and ecologically rich but increasingly fragile Yunnan, Sichuan and Tibet instead. If human rights and labour INGOs can freely set up in China, their priorities may well be Shanghai, Guangzhou and Beijing. That transnational participation is largely limited to the non-political or depoliticised layer of TCS is also reflected in INGO membership. An overwhelming majority of China memberships are in the social/health, scientific/technical, sport/ recreational, academic/professional, economic development, and welfare areas ${ }^{15}$. However, the apparent non-political or de-politicised nature of TCS penetration in China does not mean that it has no civic and political implications, as vigorously argued in the following section.

Transnational connections: democratic implications for China

Studies of TCS and the issue of democratisation have usually concentrated on campaigns by transnational NGO coalitions to make inter-governmental organisations more accountable and transparent (case studies involve the World Bank, IMF, WTO, and the various organs of the UN) ${ }^{16}$. More recently, literature has moved beyond the theme of international policy-making and started to discuss TCS impact on national processes of democratisation. Kumar examines transnational campaigns to promote democratic governance in Mexico and Haiti, while Chilton and Kaldor analyse how civil society coalitions between Eastern and Western Europe helped bringing about regime changes in some former Soviet bloc states ${ }^{17}$. On the other hand, more literature has discussed how transnational advocacy networks promoted international human rights norms in many "third world" countries. Analysis has been carried out as to how transnational NGO coalitions successfully contributed to the improvement of human rights standards in Kenya, Uganda, South Africa, Tunisia, Morocco, Indonesia, the Philippines, Chile, Guatemala and Eastern Europe ${ }^{18}$.

There is little said about China in the published literature on the theme of "transnational civil society and democratisation". One publication does mention-though in passing-transnational citizen campaigns and China's democratisation. What he has said may represent the thoughts of other scholars and thus explain why China does not figure in the discussions. Having examined the more successful cases of transnational democracy campaigns targeting Mexico and Haiti, Kumar points out:

The case of China shows just how difficult it can be to form effective transnational campaigns for democracy in other regions. There are many groups outside China pushing for democracy within the country. Most are based in the US, often supported by private American foundations, and many include prominent Chinese exiles. Yet 
their influence on US policy toward China has been limited, and their influence on China itself even less ${ }^{19}$.

Thus transnational NGO coalitions' ineffectiveness to achieve the expected results in China is due to such campaigns having to be waged outside China, unlike the other examined cases in which transnational and domestic NGOs co-ordinated their campaigns across porous national borders. This "domestic-transnational spiral model" is particularly emphasised in the theorising of the more successful transnational campaigns on democracy and human rights ${ }^{20}$.

It seems that existing literature takes seriously only those transnational campaigns involving political and/or militant INGOs and their strong and fully mobilised national counterparts. As a result, discourse of "TCS and democratisation" has avoided China since bona fide civil society capable of engaging in full-blown transnational solidarity on political issues does not exist in China, despite the activism of a handful of internationally known but domestically illegal and suppressed groups. This makes it impossible for TCS to successfully campaign for democracy and human rights in China by fully collaborating with Chinese rights NGOs.

However, I'd argue that the theme of TCS and China's democratisation is a highly relevant and worthy one. One needs to take a broader and longer-term perspective, looking beyond the usual exciting models of transnational democracy/human rights campaigns involving high-profile political INGOs like Amnesty International or Human Rights Watch in close collaboration with fully mobilised domestic civil societies of a political nature. My central argument is: though not involving any politically sensitive issue area and political or militant organisations (either Chinese or international), transnational linkages of Chinese NGOs are having now a pluralising and democratising influence at the grassroots level both subtly and gradually. This is so despite both transnational and domestic activists themselves not looking at their operations from the perspective of China's future democracy.

21 To understand this point, one needs to first see more seriously the democratising implications of Chinese "semi-civil society" itself since the transnational linkages mainly facilitate and amplify such implications. The democratising impact of the Chinese NGO community may not seem significant if one applies the dominant analytical model often used when discussing civil society's contribution to the process of democratisation. This model conditions its analysis on the prior existence of a reasonably strong civil society that is in a position to challenge and campaign against an authoritarian state ${ }^{21}$. The typical cases include some former party-states in Eastern Europe, South Korea and Taiwan during the 1980s. This threshold is too high in the Chinese case, for which a more realistic but still meaningful perspective should be adopted. Though not all NGOs in China are democratically operated, mere existence of an expanding autonomous social sector bodes well for the country's political future, even though, again, none of their activities touch on politically sensitive issues. In a context like China's, still marked by state corporatism and a socio-cultural preoccupation with family ties, any associational experience and collective voluntary activities focussed on issues and causes, thus beyond traditional family and friendship ties, is politically positive. In particular, if a top-down democratisation move occurs while individual citizens as a whole have no associational and campaign experience on basic social and environmental issues, thus remaining “a plate of sand (一盘散沙 yipan sansha)" to borrow Sun Yat Sen's (孙中山) famous saying, the democratisation process 
will be shallow and chaotic. Nick Young rightly argues that Chinese NGOs' interest in volunteerism helps create a more liberal political culture and independent citizenship. Much of this volunteering is essentially charitable in nature, described and prescribed by the Chinese groups in terms of "loving hearts", "warm heartedness", etc. This may not seem a particularly exciting manifestation of "civil society" to those who associate the term primarily with citizens' movements that shook Eastern Europe in the 1980s. But it may be a significant indicator of social capital, civic consciousness and reciprocity that help bind societies together. This is encouraging for a country where volunteering and charity were the exclusive domain of the state and social "participation" was synonymous with Leninist mass mobilisations in the not-toodistant past ${ }^{22}$. Indeed, if a bowling club is believed to have democratic effect even in the $\mathrm{US}^{23}$, one then has more reason to be encouraged by the voluntary and associational activities of Chinese YMCAs/YWCAs or other self-governing social and environmental groups. Meticulous field research co-ordinated by Young has found that even many GONGOs have been evolving into having a more autonomous relationship with the government, acquiring a more independent identity, and gradually developing a sense of themselves as belonging to a distinctive, non-government community, since they have to increasingly rely on non-governmental sources for funding and expertise and their relations with the community are more direct than those of government agencies ${ }^{24}$.

According to Pye, two major cultural obstacles to democracy in China are its rules of civility and traditional social capital. He points out: Chinese rules of civility have elaborate standards of personal civility, but they are strikingly weak in the areas of impersonal interaction; Chinese have vivid standards for superior-inferior relations, but few guidelines for the behaviour of equals; and they demonstrate over-sensitivity to any sign of antagonism, which is a serious obstacle to any legitimisation of political competition ${ }^{25}$. Pye also argues that in terms of social capital, which builds on the norms of civility and testifies to the critical level of trust among the members of a society that makes collective action possible, it has a different tradition in China. He criticises the Chinese brand of social capital as embodied in a system of guanxi (關俰), or institutionalised nepotistic personal connections among family members, friends, acquaintances with the same birthplace or from the same school ${ }^{26}$. China's NGO community as a whole, no matter how ineffective judging from the standards of an "authentic" civil society of a liberal democratic style, does in general have democratic implications in challenging those traditional rules of civility and non-liberal brand of social capital. NGOs, oriented as they are towards causes and public concerns, directed by the society's most educated and visionary elements, and featuring a spirit of volunteering for the community interests, tend to help create trust beyond family and friends, build equality and fairness in superior-subordinate relations, and encourage respect for differences in opinion and thereby allow constructive competition to take place. Operational concentration on non-political issue areas does not totally diminish such gradual democratising influences as argued earlier.

If one takes the democratising implications of China's NGO community more seriously, then logically one must also note the similar implications of the Chinese NGOs' connections with TCS, despite a concentration of co-operative efforts in functional areas or "low politics". There are two ways to read such implications. First, transnational co-operation assists the growth of the Chinese NGO sector. Second, from 
transnational sources Chinese groups receive ideas and practices which have a democratising impact.

There is a clear transnational dimension to the rise of the Chinese NGO community. As mentioned, GONGOs are created partly to receive international assistance. On the other hand, one investigation suggests that foreign NGOs' maverick activism at the NGO forum of The Fourth World Conference on Women (Beijing, 1995) was a major catalyst for the strengthened dynamism of grassroots activist NGOs in China, and many large ones are financially sustained mainly by international sources such as the Ford Foundation ${ }^{27}$. In her detailed analysis, Howell argues that China's hosting of that event resulted not only in the refashioning of the relationship of the All China Women's Federation (ACWF) with women and state, but also in the rapid proliferation of new and more autonomous women's organisations across the country. The conference exposed participants from these organisations to a range of issues being discussed by women all over the world, to the key axes of tension on controversial topics such as abortion and to diverse styles of debating. By exchanging with international feminists, Chinese activists were not only introduced to the diverse functions of NGOs, for example, as service agencies or advocates of change, but also to the plethora of imaginative ways of mobilising, communicating, organising and raising funds ${ }^{28}$. Bentley also argues that some highly-regarded women's groups such as Maple Women's Counselling Centre and Village Women Know It All got their start in the run-up to the 1995 Conference and have been supported by international funds since ${ }^{29}$.

A great number of Chinese NGOs in various issue areas have benefited from international partners (foundations, INGOs, UN agencies and governments) in capacitybuilding, programme planning, management and accountability ${ }^{30}$. In particular, significant assistance has been given by many INGOs who operate projects inside China with local partners, mainly in the areas of women, environment, public health, poverty and education ${ }^{31}$. With very extensive experiences with the transnational scene of Chinese NGOs, Tan Leshan (谭乐山), China Country Director of ORBIS International, a New York-headquartered group striving to eliminate avoidable blindness and restore sight in the developing world, elaborately argued that INGOs operating in China influenced local NGOs considerably. First, some INGOs fostered local groups, using projects to establish partner organisations. Second, INGOs often provided funding to local NGOs. Third, INGOs assisted local groups with their expertise in project management and assessment, financial auditing, grant application, thus helping to build their capacities. Very often INGOs functioned as role models for local groups ${ }^{32}$.

Aggregate social investments in China made by (or through) TCS groups operating in the country, roughly estimated to be near US $\$ 200$ million per year, is very small compared to the level of annual international commercial investment in China (roughly US $\$ 50$ billion) ${ }^{33}$. However, what matters more to the Chinese groups is that they learn from international groups new and advanced concepts originating from the expanding forums of global governance, such as international standards and a form of global rhetoric on sustainable development, endangered species, and gender-related violence, as contained in the various international treaties and UN conventions. ORBIS International is responsible for informing Chinese NGOs and health authorities of Vision 2020: The Right to Sight Global Declaration of Support, an initiative launched in 1999 by the World Health Organisation and ORBIS itself, aiming to eliminate avoidable blindness by $2020{ }^{34}$. The New York-headquartered Wildlife Conservation Society has 
been educating Chinese conservation organisations, zoos and school children on the Convention on International Trade in Endangered Species of Wild Flora and Fauna ${ }^{35}$. Those international standards are important to the Chinese groups as leverage when lobbying the authorities and as a foundation for community education. Compared to the Chinese groups, INGOs have more access to, and more first-hand experience in, international law-making in the UN's specialised agencies, treaty bodies and programmes, where key concepts, norms and conventions are debated. Citizens in China have little idea about what international treaties and conventions their government has signed and ratified. This leaves TCS as a major transmission belt of international standards and norms.

One should also mention that the many awards given to Chinese activists by international NGOs and foundations-such as The Goldman Environmental Prize (the world's largest prize honouring grassroots environmentalists) to Yu Xiaogang (于晓刚), of Green Watershed (Yunnan) in 2006 and International Banksia Award for Environment Protection to Liao Xiaoyi (廖晓义) of The Global Village of Beijing in 2001-should also encourage the further growth of their organisations. Indeed, a recently completed study by some of the leading NGO researchers in China has identified international linkages as one of the most important keys to enhance the growth of Chinese civil society ${ }^{36}$.

Transnational connections play a special facilitating role in the growth of some large and old Chinese NGOs, which enjoyed special linkages with Western groups before the coming to power of the Communist Party in 1949, and which had their activities frozen during Mao's era. A prominent example is the Shanghai YMCA, which boasts 4,000 feepaying members (the largest YMCA in China) and claims to have become a role model for YMCAs in the developing world. When it was re-established in 1984, the Shanghai YMCA was very small and weak, a shadow of its pre-1949 self. Through exchanges with international YMCAs (first with those in Japan and Hong Kong, then those in the United States, Canada, South Korea, Singapore and Malaysia), it started to develop and prosper. International YMCAs, particularly those in Japan and the United States, provided training in effective management and capacity building, helped train volunteers, and provided funding. Support and new perspectives from international sources contributed to the Shanghai YMCA's increased independence since the mid-1990s with its new emphasis on "citizen's self-management" ${ }^{37}$.

Quite apart from their expertise in their own professional issue areas, INGOs transfer democratic perspectives and practices to their Chinese partners despite the seemingly non-political nature of their co-operation, including the ideas of autonomous citizenship, grass-roots activism, public participation, direct action, issue-oriented advocacy, collective decision-making — and most importantly, a sense of "third sector". It is definitely true that INGOs like ORBIS, Save the Children and Animals Asia Foundation do not mean to be political in their China programmes, and their operators and Chinese partners do not think in terms of how their activities can be related to China's democratisation. Yet they can have a democratising effect on their Chinese partners and society at large, in the current context of China where any sign of civil society growth is good and any form of assistance to help such growth and make the Chinese groups more liberal and accountable in operation ought to be taken seriously. One example is the experience of Lions' Club International, which established branches in Guangzhou and Shenzhen in 2002. Despite its expressly non-political nature (few in 
the West would associate the Lions with democracy), the Lions has helped transform official and popular attitudes toward NGO activity by operating in China. First, there is the Lions' own democratic structure, with the members from Shenzhen and Guangzhou branches reportedly inspired by its annual presidential elections, participatory mechanism, equality among leaders and members, dedication, and transparency. Second, such culture is also influencing the operations of the two branches themselves ${ }^{38}$.

One may extrapolate from the Lions model that those numerous Chinese groups that are members of INGOs must have gained extensive democratic excises by participating in free deliberation of issues and voting. Broad socio-political ramifications can also be read with Animals Asia Foundation, a Hong-Kong-based group which campaigns globally to eliminate cruel bear farming in China, and operates a bear sanctuary in Sichuan Province. Its public education and awareness programmes regarding animal protection and its success in negotiating with the local authorities the release of caged bears have stimulated public interest in volunteering, spawned local conservation $\mathrm{NGOs,} \mathrm{and} \mathrm{encouraged} \mathrm{local} \mathrm{activists} \mathrm{to} \mathrm{see} \mathrm{the} \mathrm{value} \mathrm{of} \mathrm{direct} \mathrm{action}{ }^{39}$. This cannot but have potential significance beyond bear-related issues. Again in her study of the influence of the Fourth World Conference on Women on women's organisations in China, Howell argues that more important than learning from foreign NGOs' issuesspecific strategies, Chinese groups had the chance to broaden their view of what a NGO was, what it took to be an NGO and how it differed from a governmental agency. She rightly emphasises that this was particularly important in a country where civil society was weakly developed ${ }^{40}$. Sometimes the way to influence can be simple and direct, as demonstrated by Hands On Shanghai, founded in 2004 by a group of young foreign professionals based in the city as an affiliate of Hands On worldwide network (head office in Atlanta). It has mobilised an army of about 700 volunteers (more than half are Shanghai locals). Five times a week these people are organised to visit and help orphanages, rehabilitation centres, animal sanctuaries and various environmental projects. Richard Brubaker, Director, regards this as an effective way to reinforce to society the virtue of volunteering and help people be the change they want to see in their community ${ }^{41}$.

31 Extensive case studies have also shown that GONGOs' recent tendency towards independence has been mainly due to increased access to the international community ${ }^{42}$. Interactions with INGOs have also made some mass organisations (such as ACWF) develop a new sense of autonomy ${ }^{43}$. Imperatives in dealing with TCS makes it necessary for them to behave like NGOs and they have to be accountable to international donors. For example, Victoria Moy, Managing Director (China) of The Smile Train, a New Yorkbased organisation which seeks to provide free surgery for children in developing countries suffering from a cleft lip and palate, pointed out that her organisation successfully pushed its official partner, China Charity Federation, a major GONGO, to adopt the practice of international auditing as a precondition for donations and services, thus making its operation more transparent ${ }^{44}$.

INGOs have also gone a long way to convince the government of the value of civil society, mainly because they are mostly humanitarian and environmental "dogooders". This general conclusion was reached after my interviews in Shanghai with the country directors or programme managers of Hands On, ORBIS, The Smile Train, Wildlife Conservation Society, Project Hope, and DKT International, during September- 
October 2005. This point was particularly emphasised by C.M. Leung (梁智明), Director of Administrative Operations (China) of Project Hope, which is headquartered in Millwood, Virginia and has invested heavily in educating health professionals and providing medicines and supplies to hospitals in China ${ }^{45}$. Those organisations generally enjoy good working relations with authorities at various levels, with some like ORBIS even signing formal agreements and running joint projects with government agencies, and have contributed to the government's own social and environmental priorities. Indeed, there is no reason for the Chinese government not to embrace a group like DKT International, a Washington, D.C.-based charitable organisation whose mission is to ensure that modern contraceptive products are within easy access of low income groups for the sake of family planning and prevention of HIV/AIDS. DKT's "social marketing" in Shanghai means that low-priced but good quality condoms are delivered to "high-risk" people such as migrant workers in places like Karaoke bars ${ }^{46}$. INGOs have impressed the officials of various levels with their dedication and effectiveness. This in turn may translate into these officials' more liberal attitude towards civil society. One evidence is that despite the sensitivity due to President Bush's rhetoric on worldwide democracy promotion in his 2005 State of the Union address, the Chinese authorities did not crackdown on a training workshop held in Kunming (Yunnan) in November that year, which saw both domestic and international groups such as the USbased Sierra Club teaching university student representatives from around China (there were 40 student organisations in attendance) how to become activists, set up an $\mathrm{NGO}$, run effective campaigns, and organise protests ${ }^{47}$.

At the risk of verbosity, it is important to emphasise that while traditional Western organisations such as YWCA/YMCA, the Lions and a host of other humanitarian and charitable groups are generally not viewed as democratising in their original Western context, their transnational activities may be read differently by taking into account the unique socio-political and cultural context of the hosting non-Western societies. Such different contexts may mean that some "simple" social and humanitarian activities by those groups may have at least some indirect liberalising impact simply because a hosting society's traditional socio-political norms are so repressive that most Western-style NGO operations may look liberalising and democratising, disseminating progressive ideas and training pro-democracy behaviour. For example, Garner extensively discusses the significant role of the International YWCA and its Japanese branches in improving Japanese women's social and political status during the first half of the twentieth century, although YWCAs are generally not known in the West as staunchly feminist ${ }^{48}$. One may also cite China's own historical experience. When the prototype transnational social movements started to develop from the late nineteenth century, a handful of European housewives-turned-activists were able to spawn numerous Chinese NGOs in an anti-footbinding movement (a movement tolerated by the Qing dynasty government). These transnational advocacy campaigns, involving both Western and Chinese women activists, made considerable contributions to Chinese women's subsequent political emancipation ${ }^{49}$.

There are certainly limitations to what INGOs can achieve in their joint campaigns with local groups, even within the issue areas permitted by the government. The comparative power of Chinese civil society and authorities mean that high-profile campaigns against the government's development priorities can fail. For example, Khagram refers to the failed China campaigns by International Rivers Network and Friends of the Earth in trying to halt the big dam projects in China, symbolised by the 
mammoth Three Gorges project ${ }^{50}$. The Bush administration's rhetoric of democracy export also made Beijing sensitive to INGOs' connections with their Chinese partners. However, with the country becoming more integrated with international regimes and with the government's ever increasing need of NGOs to address immediate social and environmental tension, a "two steps forward, one step back" trajectory of China's civil society growth will continue.

The utility of transnational exchanges for China's democratisation can also be argued from their role in diluting popular nationalistic sentiment in the country. Such sentiment is rising in recent years, targeting particularly Japan and the United States. Yet at the same time a growing number of Chinese NGO operators have become involved in issues-oriented exchanges with their Western counterparts. Nationalistic fever hinders democratisation, particularly if it is manipulated by the state, a stark lesson from pre-1949 Chinese history. On the other hand, exchanges in issue areas of environment, gender, the disabled, orphans and AIDS can make societies see common concerns and shared values, and learn from each other, cultivating a sense of a "global village". Chinese people who are interested in NGOs' roles in water pollution treatment in the United States and waste processing in Japan are necessarily more detached from nationalistic ideals.

Conclusion

Chinese NGOs have expanded their connections with TCS, INGOs in particular. Cooperative projects are concentrated on the issues of gender, environment, public health, poverty and education, where the government avidly seeks assistance to tackle a range of social, environmental and rural headaches. Chinese NGOs have benefited from transnational co-operation in capacity-building, programme planning, management and accountability. More importantly, despite their apparent nonpolitical nature, transnational linkages of Chinese NGOs nurture a more healthy and autonomous third sector, thus having potentials to facilitate socio-political pluralisation. "Globalisation from below" helps China's NGOs in gradually and peacefully chipping off the country's traditional authoritarian and state/familydependent political culture, preparing a more cohesive, civil and dynamic society for the ultimate tipping moment of democratisation. It can be hoped that a "domestictransnational spiral model", with Tiananmen Mothers acting with the sort of domestic legitimacy and open transnational solidarity enjoyed by the strikingly similar Mothers of the Plaza de Mayo in the democratising Argentina in the 1990s, will become applicable in China with the progress in political reform and maturing of civil society.

\section{NOTES}

1.L.M. Salamon, "The Rise of the Nonprofit Sector", Foreign Affairs, Vol. 73, No. 4, 1994, p.109.

2.Yearbook of International Organizations 2002-03 (Munich: K. G. Saur, for the Union of International Associations, 2002), Vol. 2, p.1607. Hereafter YIO. 
3.ECOSOC website: http://www.un.org/docs/ecosoc/

4.P. Ghils, "International civil society: international non-governmental organisations in the international system", International Social Science Journal, Vol. XLIV, No. 133, 1992, pp. 421-427.

5.Nick Young, "Searching for Civil Society", in Nick Young, ed., 250 Chinese NGOs: Civil Society in the Making (internet edition), Beijing, China Development Brief, 2002. Matt Forney, "Voice of the People", Far Eastern Economic Review, May 7th 1998, pp. 10-15. 6.Nick Young, ibid.

7.The ministry's website: http://www.mca.gov.cn

8.Chan Kin-man, "Development of NGOs under a Post-Totalitarian Regime: The Case of China", presented at the International Conference on NGOs and the Nation in a Globalising World: Asia-Pacific Views, organised by Academia Sinica (Taipei) and Institute for the Study of Economic Culture (Boston University), Taipei, June 21st-22nd, 2002, p. 9.

9.Chen Jie, "Burgeoning Transnationalism of Taiwan's Social Movement NGOs", Journal of Contemporary China, Vol. 10, No. 29, 2001, pp. 613-644.

10.This is based on online database of China Development Brief (http:// www.chinadevelopmentbrief.org.cn/page.asp?sec $=4 \& s u b=4 \& p g=0$ ), a Beijing-based magazine on NGO affairs which also functions as an international consultancy group providing information and services to facilitate international NGOs' exchanges with Chinese groups.

11.Southern Weekend ( Nanfang Zhoumo) (internet edition), May 19th 2005.

12.YIO 2002-03, Vol. 2, p.1611.

13.NGO Research Center, Tsinghua University, Beijing, ed., A Nascent Civil Society Within a Transforming Environment (a report prepared for CIVICUS and released in April 2006), p. 32 .

14.NGO Research Center, ibid., p. 32.

15.YIO, various years.

16.For example, M. Edwards and J. Gaventa, Global Citizen Action, Boulder, Lynne Rienner Publishers, 2001; and P. Willetts, ed., The Conscience of the World: the influence of non-governmental organisations in the UN system, Washington, D.C., Brookings Institution, 1996.

17.C. Kumar, "Transnational Networks and Campaigns for Democracy", in Ann Florini, ed., The Third Force: The Rise of Transnational Civil Society, Tokyo, The Japan Center for International Exchange, 2000, pp. 115-142. P. Chilton, "Mechanics of Change: social movements, transnational coalitions, and the transformation processes in Eastern Europe", in R. Thomas, ed., Bringing Transnational Relations Back In: Non-State Actors, Domestic Structures and International Institutions, New York, Cambridge University Press, 1995, pp. 189-226. M. Kaldor, "The Ideas of 1989: The Origins of the Concept of Global Civil Society", in M. Kaldor, Global Civil Society: An Answer to War, Cambridge, UK, Polity, 2003, pp. 50-77.

18.A leading study is R. Thomas, S.C. Ropp and K. Sikkink, eds., The Power of Human Rights: international norms and domestic change, New York, Cambridge University Press, 1999.

19.C. Kumar, "Transnational Networks and Campaigns for Democracy", p. 137.

20.R. Thomas, "The Power of Norms versus the Norms of Power: Transnational Civil Society and Human Rights", in Ann Florini, ed., The Third Force, pp. 177-209. 
21.For example, Gordon White, "Civil Society, Democratization and Development (I): Clearing the Analytical Ground", Democratization, Vol. 1, No. 3, Autumn 1994, pp. 375-390; and Gordon White, "Civil Society, Democratization and Development (II): Two Country Cases”, Democratization, Vol. 2, No. 2, Summer 1995, pp. 56-84.

22.Nick Young, "Searching for Civil Society".

23. Robert D. Putnam, "Bowling Alone: America's Declining Social Capital”, Journal of Democracy, Vol. 6, No. 1, 1995, pp. 65-78.

24.Nick Young, "Searching for Civil Society".

25.Lucian W. Pye, "Civility, Social Capital, and Civil Society: three powerful concepts for explaining Asia”, Journal of Interdisciplinary History, xxix:4, 1999, pp. 766-769.

26.Lucian W. Pye, ibid., p. 771.

27.Deng Guosheng (邓国胜), “Changes and development in mainland China's NGOs since 1995 (1995 nian yilai dalu NGO de bianhua yu fazhan qushi)", presented at the conference "Cross-Strait Symposium on NGOs - Transformation and Development of NGOs”, hosted by Himalaya Foundation, Taipei, July 31st 2002, pp. 29-31.

28.J. Howell, "Women's Organizations and Civil Society in China: making a difference", International Feminist Journal of Politics, 5:2, 2003, pp. 191-215.

29.Julia G. Bentley, "The Role of International Support for Civil Society Organizations in China", Harvard Asia Quarterly, Winter 2003, p.16.

30.Deng Guosheng, "Changes and development in mainland China's NGOs since 1995", p. 37.

31.Nick Young, "Searching for Civil Society".

32.Interview of Tan Leshan, China Country Director, ORBIS, Shanghai, September 22nd 2005.

33.Nick Young, "NGOs: the diverse origins, changing nature and growing internationalisation of the species", in Nick Young, ed., 200 International NGOs in China: $a$ special report from China Development Brief, Beijing, 2005, p. 223.

34.Interview of Tan Leshan.

35.Interview of Li Bing (李冰), WCS program officer, Shanghai, September 29th 2005. 36.NGO Research Center, ed., A Nascent Civil Society, p. 68.

37.Interview of Wu Jianrong, General Secretary, Shanghai YMCA, September 26th 2005. 38.Susan V. Lawrence, “The Lions in the Communist Den”, Far Eastern Economic Review, August 22nd 2002, pp. 24-27.

39.Interview of Jill Robinson, CEO and Founder of Animals Asia Foundation, April 21st 2005, Perth, Australia.

40.J. Howell, "Post-Beijing Reflections: creating ripples but not waves in China", Women's Studies International Forum, 20:2, 1997, pp. 244-246.

41.Interview of Richard Brubaker, Director, Hands On Shanghai, October 1st 2005. 42.Wang Ming, Liu Guohan and He Jianyu, Reform of China's Social Organizations: from governmental preference to social preference (Zhongguo shetuan gaige: cong zhengfu xuanze dao shehui xuanze), Beijing, Social Science Works Publishing Agency, 2001, p.172. Wu Fengshi, "New Partners or Old Brothers? GONGOs in Transnational Environmental Advocacy in China", China Environment Series, No. 5, 2002, pp. 45-58.

43.Deng Guosheng, "Changes and development in mainland China's NGOs since 1995", p. 33.

44.Interview of Victoria Z. Moy, Managing Director (China), The Smile Train, Shanghai, September 23rd 2005. 
45.Interview of C.M. Leung, Director of Administrative Operations (China), Project Hope, Shanghai, September 23rd 2005.

46.Interview of Fang Kong Xin, Marketing Manager (China), DKT International, Shanghai, September 22nd 2005.

47.Russell Harwood, an Australian attendant at the 4th NGO Forum in Kunming, November 7th-11th 2005. Personal emails.

48. Karen Garner, "Global Feminism and Postwar Reconstruction: the World YWCA Visitation to Occupied Japan, 1947”, Journal of World History, Vol. 15, No. 2, 2004, pp. 191-227.

49.Margaret E. Keck and Kathryn Sikkink, "Historical Precursors to Modern Transnational Advocacy Networks", in Margaret E. Keck and Kathryn Sikkink, Activists beyond Borders: Advocacy Networks In International Politics, Ithaca and London, Cornell University Press, 1998, pp. 60-66.

50.S. Khagram, “Toward Democratic Governance for Sustainable Development: Transnational Civil Society Organizing Around Big Dams", in Ann Florini, ed., The Third Force, p. 106.

\section{ABSTRACTS}

China is no longer an outsider to the co-operation among and networking of non-governmental organisations (NGOs) across national borders. Chinese NGOs, in particular international NGOs (INGOs), have expanded their connections transnationally with civil society. Co-operative projects are concentrated in areas of gender, environment, public health, poverty and education, where the Chinese government requires assistance in tackling a range of social, environmental and rural problems associated with pro-market reform. Transnational collaboration in shared ideas, funding, advocacy and campaigns helps Chinese NGOs to provide their services and, in many cases, thus challenge the social status quo. It is also helping to further the growth of an NGO community in China. More importantly, despite their apparent non-political nature, transnational links among Chinese NGOs transfer democratising views and practices to grassroots communities and organisations, which could in turn further the country's broader socio-political development. 